\title{
Work Demands and Work Resources: Testing a Model of Factors Predicting Turnover Intentions in Early Childhood Education
}

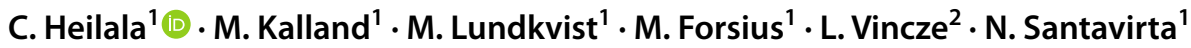

Accepted: 10 February 2021 / Published online: 24 February 2021

(c) The Author(s) 2021

\begin{abstract}
We studied the working conditions in Early Childhood Education and Care (ECEC). The aim was to explore how ECEC staff experience work demands and resources and how these relate to turnover intentions. The research was based on a modified Job Demands-Resources model (Bakker and Demerouti in J Manage Psychol 22(3):309-328, 2007) according to which job strain is influenced by both job demands and resources. The sample was identified through trade union registers and the data were collected via a survey $(N=538)$. The findings show a rather high proportion of turnover intentions. Both general workload and emotional workload were related to turnover intentions, and they were mediated by participation. However, leadership satisfaction did not mediate the relationship between workload and turnover intentions. This study contributes to the knowledge on risk factors related to intentions to leave the ECEC profession in the Finnish as well as the international context. It is urgent to know more about factors related to turnover because a high rate undermines trust in the ECEC sector and negatively impacts staff and children.
\end{abstract}

Keywords Turnover intentions · Demands · Resources · EARLY childhood

\section{Introduction}

Increasing attention is being paid to the relationship between early childhood educators' well-being and their ability to deliver high-quality education and care (Cumming 2017; Hall-Kenyon et al. 2014). Lately, the field of Early Childhood Education and Care (ECEC) in Finland has undergone policy and curriculum changes, and at the same time, the focus has shifted toward the importance of children receiving high-quality ECEC (e.g. Alila et al. 2014; Heckman 2008). As McDonald et al. (2018) state, a skilled, engaged, and professional early childhood workforce is critical for positive life trajectories among children. In order to support the development of children's wellbeing, it is important that caregivers experience wellbeing themselves (Boyer 2000).

Work-related stress and poor mental health constrain educators' abilities to deliver ECEC of high quality (Grant

C. Heilala

cecilia.heilala@helsinki.fi

1 Faculty of Educational Sciences, University of Helsinki, Helsinki, Finland

2 Swedish School of Social Science, University of Helsinki, Helsinki, Finland et al. 2016, 2018; Groeneveld et al. 2012). Working in ECEC is generally considered to be intrinsically rewarding (McDonald et al. 2018) but also emotionally demanding and challenging, as it involves close interaction with children, parents, and members of the staff (e.g. Cumming 2017; HallKenyon et al. 2014). As a result, ECEC teachers appear to be susceptible to emotional exhaustion and burnout (Barford and Whelton 2010; Cumming 2017; Jungbauer and Ehlen 2014; Koch et al. 2015; Løvgren 2016; Seery and Corrigall 2009), with rates of burnout symptoms or risk of burnout ranging from 10 to 56\% (Koch et al. 2015; Løvgren 2016; Organization for Economic Co-operation and Development [OECD] 2014).

Studies conducted internationally report turnover rates in ECEC as high as 30-40\% or even higher (Grant et al. 2019; Thorpe et al. 2020; Totenhagen et al. 2016). Turnover results in a skill loss, especially since studies report that the most qualified educators, including degree-qualified early childhood teachers, are most likely to leave the ECEC sector (Phillips et al. 2016). Reasons for turnover in ECEC are low pay, poor working conditions, and expectations to improve qualifications (Amin et al. 2003; McDonald et al. 2018; Phillips et al. 2016), whereas intentions to stay have been associated with supportive workplaces, 
opportunities for participation, having a career, and personal satisfaction (McDonald et al. 2018; Thorpe et al. 2020). The same trend can be seen in the Finnish ECEC context. A study carried out by the Finnish Ministry of Education and Culture (Eskelinen and Hjelt 2017) showed that $31 \%$ of the staff consider quitting their jobs. The reasons for this turnover are low pay, increasing workloads, and a more demanding job description, coupled with a limited scope for advancement, scarce resources, and few opportunities for participation. These factors burden the staff and lead to a shortage of these caregivers, and difficulties acquiring qualified workers. Hence, in Finland, recruiting competent staff seems to be a constant concern.

Finnish ECEC is part of the Nordic welfare tradition and builds on core values such as democracy, caring, and competence (cf. Einarsdottir et al. 2015). The values in the national core curricula are based on national and international agreements (cf. Finnish National Core Curriculum for Early Childhood Education and Care 2018; UN Convention on the Rights of the Child (UNCRC) 1989). Finnish ECEC adopts an integrated approach to care, education, and teaching with an emphasis on pedagogy. Education for children aged 0-5 years (day care) and for children aged 6 years (preprimary) is an integrated part of the educational system. All children are entitled to ECEC, and the attendance rate in 2019 was roughly $77 \%$ for children aged 1-6 years (Säkkinen and Kuoppala 2020). All 6-year-old children must attend pre-primary education. The number of ECEC staff members is regulated, based on the number of children in each group and the age of the children. Municipal day care centers are the main form of ECEC services, along with a relatively small number of publicly subsidized ECEC settings. The situation in Finland is characterized by a recent reform, which has added strain to the staff's ability to deliver quality day care. The aim of the revised law, which came into effect in September 2018, was to create well-functioning multi-professional teams with a more distinct division of labor among the staff members. One group focuses on pedagogical goals (ECEC teachers with an academic bachelor's or master's degree), the second focuses on social interaction, collaboration, and care (ECEC social workers with a polytechnic degree), and the third focuses on basic care (those with practical nurse qualifications). With a high turnover rate and shortage of staff, this goal is difficult to reach. The new legislation has caused some concern and conflicts, and the reform risks leading to job divisions that split the staff into distinct and competing groups instead of an integrated and multi-professional team. In order to be able to navigate in this new environment, we hypothesize that good leadership skills are of the utmost importance. This study focuses on Finnish ECEC staff's turnover intentions from the perspective of workload and leadership at a time when the law was not yet in effect, but in the planning (preparatory) stage and already lively debated among ECEC staff.

\section{Theoretical Frame}

The theoretical framework of the study is based on the Job Demands-Resources model developed by Bakker and Demerouti (2007). According to this model, job strain is influenced by both job demands and job resources. The demands are different aspects of the job that come with certain requirements or costs and can be exemplified by high work strain or emotionally demanding clients (Demerouti et al. 2001). The resources are the physical, psychological, social, and organizational aspects of the job that enable the achievement of goals, reduce work demands, or stimulate personal growth, learning, and development (Bakker 2011; Bakker and Demerouti 2007; Schaufeli and Taris 2014). These resources can include factors that are tied to (a) the organization as a whole, for example, salary and job security, (b) how the work is organized, for example, considerable influence over the work and a clearly defined work role, or (c) the nature of the work, for example, varied and meaningful tasks, autonomy at work and feedback (Bakker and Demerouti 2007). The resources may also include interpersonal and social relationships in the workplace, that is, the social support provided by colleagues and superiors as well as the prevailing atmosphere in the workplace.

\section{Demands: General Workload and Emotional Workload}

In our study, we define general workload and emotional workload as job-specific demands. Early childhood practice involves a high degree of emotion work (Jeon et al. 2016), which refers to work of which emotion regulation and expression are central parts and which often involves influencing someone else's feelings, behavior, or attitudes (Hochschild 1983; Näring et al. 2006; Zapf 2002; Zapf and Holz 2006). In work that involves a high degree of emotional work, in order to perform their job properly staff must express certain emotions and avoid expressing others. The staff members need to have good emotional self-regulation skills. The desirable emotional expressions are determined by spoken or unspoken display rules in the organization (Grandey 2000; Hochschild 1983). General workload refers to aspects such as time pressures and amount of work. 


\section{Resources: Leadership Satisfaction and Participation}

However, autonomy or participation at work, strong social support, and the ability to deal with one's own and others' emotions, have shown to counteract the negative consequences of emotion work (Grandey 2000; Lee and van Vlack 2018). In the ECEC context specifically, work climate, such as relationships with colleagues and perceived influence over one's work (Hur et al. 2016; Whitaker et al. 2015) are important resource factors. Perceived control and rewards have been associated with fewer burnout symptoms (Blöchliger and Bauer 2018), whereas unclear work role expectations have shown to lead to greater burnout (Goelman and Guo 1998; Løvgren 2016).

One review has shown that leadership impacts the workload and well-being of staff, although the pathways of this are still mostly unidentified (Skakon et al. 2010). The reason for this may be that the leaders create various job resources, such as quality of relationships and social support, participation in decision-making, feedback, opportunities for growth, and autonomy. The sense of community and quality of leadership have been identified as important contributing factors to job satisfaction among ECEC staff (Kusma et al. 2012). The leader both defines and influences the day care work environment (Bloom 2004; Mullis et al. 2003) and therefore affects staff well-being and job performance. The leader's task is to envision goals, affirm values, motivate staff, ensure that the staff have the same purpose, and strive for continuous improvement (Bloom 2004). However, a concern in the Finnish context is that in some cases, center directors are remote from daily practice and pedagogical leadership is shared with the teachers (Heikka et al. 2018). Therefore, the qualifications of ECEC teachers are not the only important aspect; their ability to create and develop fruitful practices and pedagogical environments are also essential (Sims and Waniganayake 2015; Venninen et al. 2012). To establish and maintain a well-functioning day care environment, a prerequisite is trust between the director and the staff, as well as an even distribution of responsibilities and power between different organizational levels (Burke et al. 2007).

The nature of the ECEC context has been regarded as so challenging and complex that it requires the efforts of more than just a single person or a single team (O'Connor and Day 2007). However, there has been an increasing interest in distributive leadership, even though research on this has focused more on the school sector and has been scarce in ECEC contexts (Colmer et al. 2015; Heikka 2014). One review study (Heikka et al. 2013) suggests that distributive leadership has a positive effect not only on teachers and leaders but also on education, as long as the leadership is well managed, goal oriented, and continuously planned and developed. Distributed leadership has also been seen to encourage development practices and highlight the role of the staff in the development process (Kangas et al. 2016).

In sum, multiple job demands and the newly revised act implicate new demands for ECEC leadership to enable different categories of staff to find their identity and to specify their roles and their competencies so that the staff can work together as a multi-professional and unified team. This requires a good work climate in which all stakeholders are valued and appreciated members who can participate in decision-making (Ebbeck and Waniganayake 2003; Rodd 2013).

\section{Aims of the Study}

This study focuses on how ECEC staff groups experience work demands (general workload and emotional workload) and resources (leadership satisfaction and participation) and how these relate to turnover intentions. We hypothesize that workload factors, employee participation in planning and decision-making, and the employee's satisfaction with leadership play an important role in estimating and preventing intentions to leave the profession. The aim was to analyze the relationships between intentions to quit the ECEC profession and workload, including emotional workload, the employee's view of their relations with the leader, and their participation in planning and decision-making in daily work. We also tested whether leadership satisfaction and participation may mediate the relations between workload and turnover intentions. This means that when staff experience higher satisfaction with their leader and higher degrees of participation, despite their workload, they will have lower turnover intentions. Hence, the study seeks to test a model in the whole sample with leadership satisfaction and participation as mediating factors between workload and turnover intentions (Fig. 1).

The specific research questions are:

- How does the staff perceive their demands and resources and do staff groups differ from each other?

- Is there a relationship between workload and turnover intentions?

- Is there a relationship between workload and leadership satisfaction?

- Is there a relationship between workload and participation?

- Do leadership satisfaction and participation mediate the relationship between workload and turnover intentions?

Our hypotheses were that: 
Fig. 1 Mediating model for relationships between workload and turnover intentions. X (emotional work and workload) represents the independent variables, $\mathrm{Y}$ (turnover) is the dependent variable and $\mathrm{M}$ (leadership satisfaction and participation) represents the variables that mediate the relationships between $\mathrm{X}$ and $\mathrm{Y}$

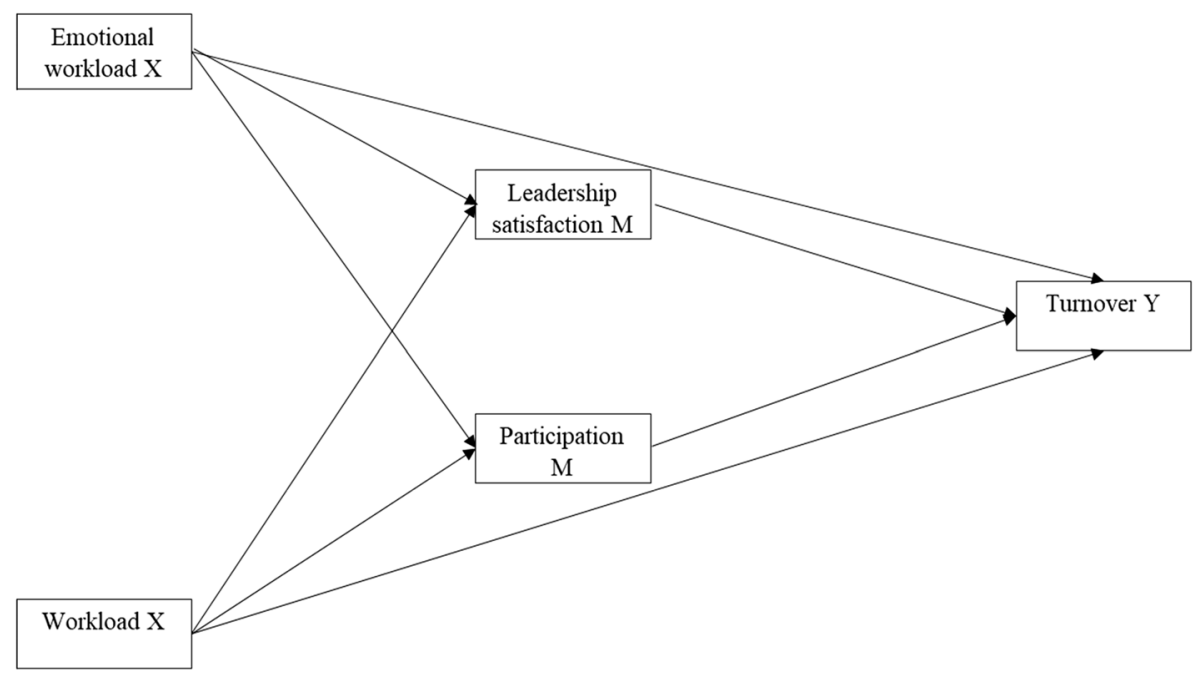

1. Emotional workload and (general) workload are directly related to turnover intentions.

2. Participation and leadership buffer the effect of workload (both emotional and general) on intentions to leave and are thus indirectly related to turnover intentions.

\section{Methods}

\section{Sample and Data-Collecting Procedure}

Data were collected in May 2018 via an electronic survey. The sample was identified through the registers of three main trade unions. In Finland, 73\% of all workers were members of a trade union in 2017 (Findicator 2019). Altogether 3635 surveys were sent to all categories of ECEC staff, covering the whole country. Of these, 676 surveys $(18.6 \%)$ were returned and $n=33$ were excluded due to too much missing data. Leaders and assistant leaders $(n=62)$ were also excluded. In addition, $n=43$ did not meet the qualification criteria for their positions and were excluded. The final sample consisted of $N=538$ informants $(14.5 \%)$. The average age was $37.2(s d=9.20)$, the youngest teacher was 21 , whereas the oldest was 64 years old. Of the staff, 138 (25.3\%) were early childhood education teachers (university bachelor's degree), 272 (49.9\%) were social workers in early childhood education (polytechnic), and 128 (23.5\%) were licensed practical nurses.

\section{Measures}

The electronic survey consisted of separate variables and standardized validated scales including 106 items that were divided into eight different aspects. In the current study, we looked at sociodemographic variables (age, education), and questions on workload and emotional workload, intentions to leave job and change profession, leadership satisfaction, and perception of opportunities to participate in planning and in decision-making.

\section{Sociodemographic Variables}

Education was measured by asking the respondents to choose one of five options (a) teaching degree, bachelor's in education; (b) social work degree or similar qualification; (c) licensed practical nurses or similar qualification; (d) master's in education; or (e) other. People who did not have qualifications suitable for the ECEC context were excluded, which resulted in a sample that included only qualified staff.

\section{Demands: Workload and Emotional Workload}

Workload was measured by four items on a Likert-type scale ranging from one to five ("The workload is acceptable", "The resources are adequate") and all items were recoded so that $1=$ low demands to $5=$ high demands. Cronbach's alpha for the sum scale was $\alpha=.86$. The items were inspired by the Job-Demand Resources model (Bakker and Demerouti 2007) and the Job-Demand Resources scale (Jackson and Rothmann 2005). 
Items related to emotional workload and work-related emotional requirements were measured by eight items. The items were based on the Frankfurt Emotion Work Scale (FEWS; Zapf et al. 1999) (e.g., "My work includes situations that arouse feelings within me", "In my job I often have to suppress emotions in order to appear 'neutral' on the outside"). The scale ranged from $1=$ completely disagree to $5=$ completely agree. Principal component analysis was conducted to investigate the structure of the scale and for the sake of dimension reduction. Two items had low communality, $h^{2}<.10$, and were therefore excluded from further analysis. In the final factor solution, two components emerged with four items loading to component one and two items loading to component two. The rotation method was Varimax, loading was set at $\geq .40$ and the final factor solution explained $66 \%$ of the variance. The first component was named emotional workload and reflected an emotional discrepancy or conflict between feeling and overt reaction and behavior. We constructed a sum scale based on these four variables, $\alpha=.81$. The second component reflected workrelated emotional requirements, but the alpha coefficient was fairly low at $\alpha=0.57$ and thus this component was not further used in the study.

\section{Resources: Leadership Satisfaction, Opportunities to Participate}

This section consists of 18 items divided into three categories that reflect the different aspects of the work environment (participation; fair task distribution among colleagues and social support in the job). All items were measured by a Likert-type scale ranging from $1=$ completely disagree to $5=$ completely agree. The items were inspired by the JobDemand Resources model (Bakker and Demerouti 2007) and the Job-Demand Resources scale (Jackson and Rothmann 2005). Data reduction applied Principal Component Analysis with Varimax rotation and loading set at $\geq .40$. The final factor solutions resulted in two components, which were named Participation and Leadership satisfaction. Participation was measured by eight items (e.g. "I am involved in the planning of my work", "I can influence my work",), $\alpha=.86$, and leadership satisfaction was measured by 4 items ("I feel appreciated by the director", "I get enough guidance in my work"), $\alpha=.87$. Table 1 presents the four sum scales.

Table 1 Sum scales, reliability and range

\begin{tabular}{|c|c|c|}
\hline Scale & Alpha & Range \\
\hline $\begin{array}{l}\text { Workload } \\
\text { The workload is acceptable } \\
\text { I have enough time to complete my tasks } \\
\text { The demands are reasonable } \\
\text { The resources are adequate }\end{array}$ & .86 & $1-5$ \\
\hline $\begin{array}{l}\text { Emotional workload } \\
\text { In my job I often have to express emotions towards children which do not match my actual feelings } \\
\text { In my job I often have to express emotions towards parents which do not match my true feelings } \\
\text { In my job I often have to suppress emotions in order to appear 'neutral' on the outside } \\
\text { I often have to exaggerate emotions (positive/negative) on the outside while actually feeling indifferent inside }\end{array}$ & .81 & $1-5$ \\
\hline $\begin{array}{l}\text { Participation } \\
\text { I receive sufficient information on decisions that involve me } \\
\text { I am involved in the planning of my work } \\
\text { My views and ideas are taken into account when planning the activities } \\
\text { I can express different views to the director } \\
\text { I can influence my work } \\
\text { I have sufficient rights to make decisions } \\
\text { I get to use the skills and competencies I have } \\
\text { I have sufficient opportunities for personal growth in my work }\end{array}$ & .86 & $1-5$ \\
\hline $\begin{array}{l}\text { Leadership satisfaction } \\
\text { I get on well with the director } \\
\text { I feel appreciated by the director } \\
\text { I get enough guidance from the director } \\
\text { I get enough guidance in my work }\end{array}$ & .87 & $1-5$ \\
\hline
\end{tabular}

All sum scales were made using the mean function 


\section{Turnover Intentions}

Intentions to quit the ECEC profession and leave the sector were elicited by one item ("Do you plan to change profession?") which was dichotomous and coded as $1=$ yes $/ 0=$ no. This variable measured the potential to quit the profession and leave the ECEC sector altogether.

The study follows the Ethical principles of research in the humanities and social and behavioral sciences and proposals for ethical review (2009) issued by the Finnish National Board on Research Integrity (TENK). As the data collection was electronic, it was anonymous.

\section{Statistical Methods}

\section{Data Analysis}

Data reduction of the scales was conducted using principal component analysis, which is described in detail in the Measures section. The reliability of the scales was measured using Cronbach's alpha coefficient. Differences between the groups were calculated using ANOVA. The relationship between two nominal variables was measured using $\chi^{2}$. A point-biserial correlation was run to determine the relationship between turnover and continuous variables using the Pearson correlation coefficient. The theoretical model was tested using PROCESS macro (Hayes 2017). Bootstrapped confidence intervals for the indirect effects were computed on the basis of 5000 samples. IBM SPSS Statistics 24 was used to analyze the data. Statistical significance was accepted if $p>.05$.

\section{Results}

\section{How does the Staff Perceive Their Demands and Resources and do Staff Groups Differ from Each Other?}

Table 2 presents the means, standard deviations, reliability coefficients, and correlations among the variables included in the study. The variables were positively and significantly related, showing small and moderate correlation coefficients. The staff seems to perceive their opportunities to participate as good. The three staff groups did not significantly differ in these variables. Nevertheless, they reported a high average level of workload and a fairly high level of emotional workload. Regarding emotional workload, no statistically significant difference between the three staff groups was found. However, workload differed statistically significantly, with ECEC teachers (Bachelor) scoring highest $M_{\text {ped }}=3.8, M_{\text {soc }}=3.6$ and $M_{\text {nurs }}=3.3, F(2,535)=11.684$, $p<.001$. Leadership satisfaction also differed statistically significantly, with ECEC teachers (Bachelor) scoring lowest $F(2,533)=3.693, p<.05\left(M_{\text {ped }}=3.8, M_{\text {soc }}=4.0, M_{\text {nurs }}=4.0\right)$. Turnover intentions were rather high, with more than half reporting intentions to quit their ECEC profession. Turnover differed statistically significantly between the groups $\left(\chi^{2}(2)=8.177, p<.05\right)$, with ECEC teachers having the highest proportion of turnover intentions at $61.3 \%$; ECEC social workers at $55.4 \%$ and nurses at $44.0 \%$.

\section{Correlations Between the Variables Included in the Model}

Workload and emotional workload correlated positively with turnover intentions. Workload explained $9.6 \%$ of intentions to leave the ECEC profession, whereas emotional workload explained $9.1 \%$. Workload and leadership satisfaction correlated negatively, and workload explained $13.8 \%$ of the
Table 2 Means, standard deviations, and correlation coefficients between variables included in model

\begin{tabular}{|c|c|c|c|c|c|c|c|c|}
\hline$n(\%)$ & & $M$ & $S D$ & 1 & 2 & 3 & 4 & 5 \\
\hline \multicolumn{9}{|l|}{ Demands } \\
\hline 1. Emotional workload & & 3.0 & .87 & - & & & & \\
\hline 2. Workload & & 3.6 & .97 & $.202 * *$ & - & & & \\
\hline \multicolumn{9}{|l|}{ Resources } \\
\hline 3. Leadership satisfaction & & 4.0 & .73 & $-.157 * *$ & $-.371 * *$ & - & & \\
\hline 4. Participation & & 3.8 & .74 & $-.211 * *$ & $-.390 * *$ & $.666^{* *}$ & - & \\
\hline 5. Turnover intentions & & & & $.310 * *$ & $.301 * *$ & $-.217 * *$ & $-.294 * *$ & - \\
\hline Yes & $289(54.2)$ & & & & & & & \\
\hline No & $244(45.8)$ & & & & & & & \\
\hline
\end{tabular}

$M$ and $S D$ represent mean and standard deviation, respectively

***Correlation is significant at the 0.01 level (2-tailed) 
variance. Emotional workload and leadership satisfaction correlated negatively, and the determination coefficient $\left(r^{2}\right)$ was $2.5 \%$. Workload and participation correlated negatively, with a determination coefficient of $15.2 \%$. Emotional workload and participation correlated negatively, and the effect was $2.5 \%$.

Leadership satisfaction correlated negatively with turnover intentions and explained $4.7 \%$ of the variance of intentions to leave ECEC, and participation also correlated negatively with turnover intentions and explained $8.6 \%$ of the variance. There was also a high positive correlation between participation and leadership satisfaction $\left(r^{2}=44 \%\right)$.

\section{Relationships Between Workload, Work Environment Factors, and Turnover Intentions}

The full model was significant, $\chi^{2}(4)=105.99, p<.001$, and according to Nagelkerke, pseudo- $R^{2}$ explained about $24 \%$ of the variation in the dependent variable (turnover intentions). Figure 2 summarizes the unstandardized regression coefficients.

The indirect effects of neither emotional workload, $B=-.003,95 \%$ CI $[-.04, .02]$, nor workload $B=-.01$, $95 \%$ CI $[-.10, .09]$, were significant in terms of leadership satisfaction. However, the indirect effects of both emotional workload, $B=.07,95 \%$ CI $[.02, .14]$, and workload, $B=.17$, $95 \%$ CI $[.07, .29]$, were significant in terms of perceived participation. Thus, the way in which the staff perceived their opportunities to participate in their work environment (planning decisions and implementing them) mediated their intentions to leave the ECEC profession.

\section{Discussion}

The results of our study showed that a rather high proportion of ECEC staff consider quitting the ECEC profession (44-62\%). Intentions to leave differed statistically significantly between the groups, with ECEC teachers having the highest proportion of turnover intentions (62\%). Turnover intentions in Finland have previously been reported as being as high as 31\% for all staff and 39\% for teachers (Eskelinen and Hjelt 2017). This is in line with previous international studies reporting turnover figures of up to $30-40 \%$ or higher (Grant et al. 2019; Thorpe et al. 2020; Totenhagen et al. 2016), often attributed to challenging working conditions and low pay (Amin et al. 2003; McDonald et al. 2018; Phillips et al. 2016). The results show that workload, both general and emotional, was also high on average. We found significant differences in general workload, with the ECEC teachers scoring higher than the others. The groups did not differ in terms of emotional workload. Leadership satisfaction was high on average among the staff, but significant differences were found, with the teachers scoring lower than the others. Participation was high on average among the staff, and the groups did not differ, which is a good result, as it shows that all the staff groups perceived having similar opportunities to participate. However, the distribution had variance. The suspicion of division between the staff groups due to the new law could only partly be confirmed in this study because emotional workload and participation did not differ in the three profession groups. The law was not yet in force at the time of data collection, but it is highly important that we follow its effects as its purpose is to strive toward seamless, unified multi-professional teamwork in order to enhance work engagement and prevent turnover. ECEC teachers in particular, who seem to express the highest turnover and general workload combined with lower
Fig. 2 Results of the mediating model. Unstandardized regression coefficients (B) for the relationships between workload, work environment factors and turnover intentions

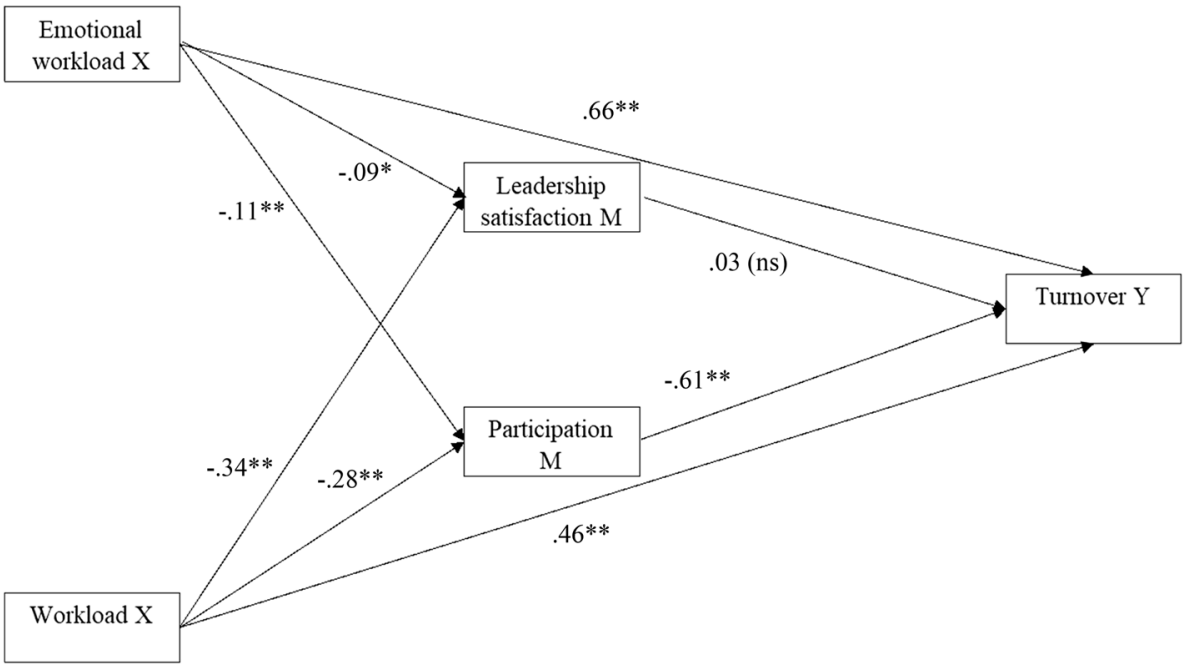


leadership satisfaction, need to be carefully followed. This is in line with previous reports that the most qualified educators, including degree-qualified early childhood teachers, are most likely to leave the ECEC sector (Phillips et al. 2016). The higher turnover among the teachers may possibly be due to expectations to gain qualifications (McDonald et al. 2018; Phillips et al. 2016).

We hypothesized that job demands (general workload and emotional workload factors), and resource factors (employee's sense of participation, as well as employee satisfaction with leadership) are all related to intentions to leave directly and indirectly. The results give partial support to this hypothesis, as both general workload and emotional workload are related to intentions to leave and are mediated by participation. Previous studies show that work climate, such as relationships with colleagues and perceived job influence (Hur et al. 2016; Whitaker et al. 2015), are important resource factors and that personal satisfaction as well as supportive workplaces are related to intentions to stay (Thorpe et al. 2020). Somewhat surprisingly, in this study, the employee's satisfaction with leadership did not mediate the relationship between workload and intentions to leave the ECEC profession. However, leadership satisfaction had a strong and statistically significant positive zero order correlation with participation.

The reasons for our results can probably partly be traced to the fact that our leadership satisfaction was not measured on the basis of a theory or standardized instrument. This does not change the fact that leadership is one of the key factors in preventing turnover intentions, or that community and quality of leadership have been identified as important factors contributing to job satisfaction among ECEC staff (Kusma et al. 2012). As discussed earlier, it is the job of the leader to both define and affect the day care work environment (Bloom 2004; Mullis et al. 2003) as well as staff wellbeing and job performance. It is also important to envision goals, affirm values, motivate staff, ensure that staff have the same purpose, and strive for continuous improvement (Bloom 2004). Alongside these factors, the opportunity to participate in decision-making and influencing one's job is also related to leadership: in fact, it is a vital component of distributed leadership. The results in this study may reflect how distributed leadership mediates the impact of workload on intentions to leave the ECEC profession, while satisfaction with leadership per se does not.

It has been suggested that distributive leadership has positive returns in this context, as long as continuous attention is paid to how leadership is organized, planned and developed (Heikka et al. 2013). A prerequisite for efficient leadership would hence be that all staff members perceive themselves as valued team members and feel that they actively take part in decision-making (Ebbeck and Waniganayake 2003; Rodd 2013). However, the Finnish context faces challenges in the form of directors who are remote from daily activities and a pedagogical leadership that is shared with the teachers (Heikka et al. 2018). Therefore trust, as well as the distribution of responsibilities and power between different organizational levels, are essential aspects (Burke et al. 2007). Not only the qualifications of ECEC teachers are important; their ability to create and develop fruitful practices and pedagogical environments is also central (Sims and Waniganayake 2015; Venninen et al. 2012).

To conclude, ECEC staff perceive their general and emotional workload as high. The proportion of intentions to leave the ECEC profession is rather high and the requirements of the revised law pose the risk of a split among the staff. Leadership in this situation requires the distribution of tasks and responsibilities that authorize staff members to independently conduct and develop their work roles and work identities in order to work as a well-functioning multiprofessional team. The role of the leader will be to create an atmosphere of active participation and togetherness. Therefore, to create well-functioning multi-professional teams, good leadership that emphasizes participation seems to be of utmost importance.

\section{Limitations}

We are aware of the limitations of cross-sectional studies and therefore cannot make any causal inferences about turnover intentions and the factors related to demands and resources. The data in this study were self-reported and social desirability bias is a potential risk factor, even though the data were collected anonymously. The response rate being relatively low (14.5\%), we cannot assume that the sample was representative of the work force in ECEC. The possibility of attrition bias or unequal loss of participants from study groups must be taken into account, as the response rate of social workers was higher than that of the teachers and nurses. Also, we cannot rule out the possibility that persons who were more likely to leave have replied to our survey, especially since the data was gathered at a time when the new law was in the planning (preparatory) stage and already lively debated among ECEC staff. As the respondents had to belong to a trade union, workers who did not were excluded from this study. However, trade union member rates are relatively high in Finland, with $73 \%$ of all workers belonging to a trade union in 2017 (Findicator 2019). In this study we focused on the relation between turnover intentions and factors related to workload and leadership satisfaction, and we believe that the relations between turnover intentions and other factors are likely to be replicated in other samples. Also, the fact that we studied turnover intentions when the law was still in a preparatory stage gives us the possibility to compare the turnover outcomes of the new law in a follow-up study. 
We used measures inspired by validated scales and single-item measures in the study. The reason for this was that none of the validated scales were completely suitable for the ECEC context. One concern is the use of single-item measures for the dependent variable (turnover intentions).

Funding Open access funding provided by University of Helsinki including Helsinki University Central Hospital.

\section{Compliance with Ethical Standards}

Conflict of interest The authors report no conflict of interest.

Open Access This article is licensed under a Creative Commons Attribution 4.0 International License, which permits use, sharing, adaptation, distribution and reproduction in any medium or format, as long as you give appropriate credit to the original author(s) and the source, provide a link to the Creative Commons licence, and indicate if changes were made. The images or other third party material in this article are included in the article's Creative Commons licence, unless indicated otherwise in a credit line to the material. If material is not included in the article's Creative Commons licence and your intended use is not permitted by statutory regulation or exceeds the permitted use, you will need to obtain permission directly from the copyright holder. To view a copy of this licence, visit http://creativecommons.org/licenses/by/4.0/.

\section{References}

Alila, K., Eskelinen, M., Estola, E., Kahiluoto, T., Kinos, J., Pekuri, H.-M., et al. (2014). Varhaiskasvatuksen, historia, nykytila ja kehittämisen suuntalinjat. Tausta-aineisto varhaiskasvatusta koskevaa lainsäädäntöä valmistelevan työryhmän tueksi (The history, present state and future perspectives of early childhood education). Helsinki: Ministry of Education and Culture.

Amin, M. R., Zaman, A., \& Amin, N. A. (2003). Organizational profile, HR practices and the perceived quality and performance of small businesses: Empirical highlights from the urban child care centers. International Business and Economics Research Journal, 2(6), 95-105. https://doi.org/10.19030/iber.v2i6.3813.

Bakker, A. B. (2011). An evidence-based model of work engagement. Current Directions in Psychological Science, 20(4), 265-269. https://doi.org/10.1177/0963721411414534.

Bakker, A. B., \& Demerouti, E. (2007). The job demands-resources model: State of the art. Journal of Managerial Psychology, 22(3), 309-328. https://doi.org/10.1108/02683940710733115.

Barford, S. W., \& Whelton, W. J. (2010). Understanding burnout in child and youth care workers. Child \& Youth Care Forum, 39(4), 271-287. https://doi.org/10.1007/s10566-010-9104-8.

Blöchliger, O. R., \& Bauer, G. F. (2018). Correlates of burnout symptoms among child care teachers. A multilevel modeling approach. European Early Childhood Education Research Journal, 26(1), 7-25. https://doi.org/10.1080/1350293X.2018.1412012.

Bloom, P. (2004). Leadership as a way of thinking. Zero to Three, 25, $21-26$.

Boyer, W. (2000). Care for the caregivers: An intrapersonal journey. International Journal of Early Childhood, 32(1), 41-48. https:// doi.org/10.1007/BF03169022.
Burke, C. S., Sims, D. E., Lazzara, E. H., \& Salas, E. (2007). Trust in leadership: A multi-level review and integration. The Leadership Quarterly. https://doi.org/10.1016/j.leaqua.2007.09.006.

Colmer, K., Waniganayake, M., \& Field, L. (2015). Implementing curriculum reform: Insights into how Australian early childhood directors view professional development and learning. Professional Development in Education, 41(2), 203-221. https://doi. org/10.1080/19415257.2014.986815.

Cumming, T. (2017). Early childhood educators' well-being: An updated review of the literature. Early Childhood Education Journal, 45(5), 583-593. https://doi.org/10.1007/s10643-016-0818-6.

Demerouti, E., Bakker, A., Nachreiner, F., \& Schaufeli, W. (2001). The job demands-resources model of burnout. The Journal of Applied Psychology, 86, 499-512. https://doi. org/10.1037/0021-9010.86.3.499.

Ebbeck, M., \& Waniganayake, M. (2003). Early childhood professionals: Leading today and tomorrow. Sydney: McLennan \& Petty.

Einarsdottir, J., Purola, A.-M., Johansson, E., Broström, S., \& Emilson, A. (2015). Democracy, caring and competence: values perspectives in ECEC curricula in the Nordic countries. International Journal of Early Years Education, 23(1), 97-114.

Eskelinen, M., \& Hjelt, H. (2017). Varhaiskasvatuksen henkilöstö ja lapsen tuen toteuttaminen. Valtakunnallinen Selvitys 2017 (Early education and care staff and the implementation of support activities for children. National Survey 2017). Helsinki: Ministry of Education and Culture.

Findicator. (2019). Membership in employee organisations. Statistics Finland. Retrieved December 15, 2020, from https://findikaattori. fi/en/36

Finnish National Agency for Education. (2018). National core curriculum for early childhood education and care 2018. Helsinki: Finnish National Agency for Education.

Finnish National Board on Research Integrity (TENK). (2009). Ethical principles of research in the humanities and social and behavioural sciences and proposals for ethical review. Retrieved March 02, 2018, from http://www.tenk.fi/en/ethical-review-in-finland.

Goelman, H., \& Guo, H. (1998). What we know and what we don't know about burnout among early childhood care providers. Child Youth Care Forum, 27, 175-199. https://doi.org/10.1007/BF025 89564.

Grandey, A. A. (2000). Emotional regulation in the workplace: A new way to conceptualize emotional labor. Journal of Occupational Health Psychology, 5(1), 95-110. https://doi. org/10.1037/1076-8998.5.1.95.

Grant, A. A., Jeon, L., \& Buettner, C. K. (2019). Relating early childhood teachers' working conditions and well-being to their turnover intentions. Educational Psychology, 39(3), 294-312. https:// doi.org/10.1080/01443410.2018.1543856.

Grant, S., Comber, B., Danby, S., Theobald, M., \& Thorpe, K. (2018). The quality agenda: Governance and regulation of preschool teachers' work. Cambridge Journal of Education, 48(4), 515-532. https://doi.org/10.1080/0305764x.2017.1364699.

Grant, S., Danby, S., Thorpe, K., \& Theobald, M. (2016). Early childhood teachers' work in a time of change. Australasian Journal of Early Childhood, 41(3), 38-45. https://doi.org/10.1177/18369 3911604100306.

Groeneveld, M. G., Vermeer, H. J., van Ijzendoorn, M. H., \& Linting, M. (2012). Caregivers' cortisol levels and perceived stress in home-based and center-based childcare. Early Childhood Research Quarterly, 27, 166-175. https://doi.org/10.1016/j.ecres q.2011.05.003.

Hall-Kenyon, K., Bullough, R. V., MacKay, K. L., \& Marshall, E. E. (2014). Preschool teacher well-being: A review of the literature. Early Childhood Education Journal, 42(3), 153-162. https://doi. org/10.1007/s10643-013-0595-4. 
Hayes, A. F. (2017). Introduction to mediation, moderation, and conditional process analysis: A regression-based approach. New York: The Guilford Press.

Heckman, J. (2008). Schools, skills, and synapses. Economic Inquiry, 46(3), 289-324.

Heikka, J. (2014). Distributed pedagogical leadership in early childhood education. Tampere: Tampere University Press.

Heikka, J., Waniganayake, M., \& Hujala, E. (2013). Contextualizing distributed leadership within early childhood education: Current understandings, research evidence and future challenges. Educational Management Administration \& Leadership, 41(1), 30-44. https://doi.org/10.1177/1741143212462700.

Heikka, J., Halttunen, L., \& Waniganayake, M. (2018). Perceptions of early childhood education professionals on teacher leadership in Finland. Early Child Development and Care, 188(2), 143-156. https://doi.org/10.1080/03004430.2016.1207066.

Hochschild, A. R. (1983). The managed heart: Commercialization of human feeling. New York: University of California Press.

Hur, E., Jeon, L., \& Buettner, C. K. (2016). Preschool teachers' childcentered beliefs: Direct and indirect associations with work climate and job-related wellbeing. Child \& Youth Care Forum, 45(3), 451-465. https://doi.org/10.1007/s10566-015-9338-6.

Jackson, L., \& Rothmann, S. (2005). Work-related well-being of educators in a district of the north-west province. Perspectives in Education, 23, 107-122.

Jeon, L., Buettner, C. K., \& Hur, E. (2016). Preschool teachers' professional background, process quality, and job attitudes: A personcentered approach. Early Education and Development, 27(4), 551-571. https://doi.org/10.1080/10409289.2016.1099354.

Jungbauer, J., \& Ehlen, S. (2014). Stress and burnout risk in nursery school teachers: Results from a survey. Das Gesundheitswesen. https://doi.org/10.1055/s-0034-1381995.

Kangas, J., Venninen, T., \& Ojala, M. (2016). Distributed leadership as administrative practice in finnish early childhood education and care. Educational Management Administration \& Leadership, 44(4), 617-631. https://doi.org/10.1177/1741143214559226.

Koch, P., Stranzinger, J., Nienhaus, A., \& Kozak, A. (2015). Musculoskeletal symptoms and risk of burnout in child care workersA cross-sectional study. PLoS ONE, 10, e0140980. https://doi. org/10.1371/journal.pone.0140980.

Kusma, B., Groneberg, D.A., Nienhaus, A. \& Mache, S. (2012). Determinants of day care teachers' job satisfaction. Central European Journal of Public Health, 20(3), 191-198. https://doi. org/10.21101/cejph.a370.

Lee, M., \& van Vlack, S. (2018). Teachers' emotional labour, discrete emotions, and classroom management self-efficacy. Educational Psychology, 38(5), 669-686. https://doi.org/10.1080/01443 410.2017.1399199.

Løvgren, M. (2016). Emotional exhaustion in day-care workers. European Early Childhood Education Research Journal, 24(1), 157167. https://doi.org/10.1080/1350293X.2015.1120525.

McDonald, P., Thorpe, K., \& Irvine, S. (2018). Low pay but still we stay: Retention in early childhood education and care. Journal of Industrial Relations, 60, 647-668. https://doi.org/10.1177/00221 85618800351.

Mullis, A., Cornille, T., Mullis, R., \& Taliano, K. (2003). Childcare center directors' perceptions of their work environments: A comparison of for-profit and non-profit programs. Early Child Development and Care, 173(5), 545-556. https://doi.org/10.1080/03004 43032000086890.

Näring, G., Briët, M., \& Brouwers, A. (2006). Beyond demand-control: Emotional labour and symptoms of burnout in teachers. Work \& Stress, 20(4), 303-315. https://doi.org/10.1080/0267837060 1065182.
O'Connor, P. M. G., \& Day, D. V. (2007). Shifting the emphasis of leadership development: From "me" to "all of us." In J. A. Conger \& R. E. Riggio (Eds.), The practice of leadership: Developing the next generation of leaders (pp. 64-86). San Francisco: Jossey-Bass.

Organization for Economic Co-operation and Development [OECD]. (2014). Encouraging quality in early childhood education and care. In Research brief: Working Conditions matter. Retrieved February 05, 2020, from http://www.oecd.org/education/schoo 1/49322250.pdf

Phillips, D., Austin, L., \& Whitebook, M. (2016). The early care and education workforce. The Future of Children, 26(2), 139-158. https://doi.org/10.1353/foc.2016.0016.

Rodd, J. (2013). Leadership in Early Childhood. The pathway to professionalism. McGraw-Hill Open University Press.

Säkkinen, S. \& Kuoppala, T. (2020). Tilastoraportti 33/2020 (Statistics report 33/2020). Finnish institute for health and welfare. Retrieved December 15, 2020, from http://urn.fi/URN:NBN:fi-fe20200929 76135 .

Schaufeli, W. B., \& Taris, T. W. (2014). A critical review of the job demands-resources model: Implications for improving work and health (pp. 43-68). Dordrecht: Springer.

Seery Brenda, L., \& Corrigall Elizabeth, A. (2009). Emotional labor: Links to work attitudes and emotional exhaustion. Journal of Managerial Psychology, 24(8), 797-813. https://doi. org/10.1108/02683940910996806.

Sims, M., \& Waniganayake, M. (2015). The role of staff in quality improvement in early childhood. Journal of Education and Training Studies. https://doi.org/10.11114/jets.v3i5.942.

Skakon, J., Nielsen, K., Borg, V. \& Guzman, J. (2010). Are leaders' well-being, behaviours and style associated with the affective well-being of their employees? A systematic review of three decades of research. Work \& Stress, 24(2), 107-139. https://doi. org/10.1080/02678373.2010.495262

Thorpe, K., Jansen, E., Sullivan, V., et al. (2020). Identifying predictors of retention and professional wellbeing of the early childhood education workforce in a time of change. Journal of Educational Change, 21, 623-647. https://doi.org/10.1007/s10833-020-09382 -3 .

Totenhagen, C. J., Hawkins, S. A., Casper, D. M., Bosch, L. A., Hawkey, K. R., \& Borden, L. M. (2016). Retaining early childhood education workers: A review of the empirical literature. Journal of Research in Childhood Education, 30(4), 585-599. https://doi.org/10.1080/02568543.2016.1214652.

UNCRC. (1989). Convention on the rights of the child. Retrieved December 15, 2020, from https://downloads.unicef.org.uk/wp-conte nt/uploads/2010/05/UNCRC_PRESS200910web.pdf?_ga=2.78590 034.795419542.1582474737-1972578648.1582474737

Venninen, T., Leinonen, J., Ojala, M., \& Lipponen, L. (2012). Creating conditions for reflective practice in early childhood education. International Journal of Child Care and Education Policy, 6(1), 1-15. https://doi.org/10.1007/2288-6729-6-1-1.

Whitaker, R. C., Dearth-Wesley, T., \& Gooze, R. A. (2015). Workplace stress and the quality of teacher-children relationships in head start. Early Childhood Research Quarterly, 30, 57-69. https://doi. org/10.1016/j.ecresq.2014.08.008.

Zapf, D. (2002). Emotion work and psychological well-being: A review of the literature and some conceptual considerations. Human Resource Management Review, 12(2), 237-268. https:// doi.org/10.1016/S1053-4822(02)00048-7.

Zapf, D., \& Holz, M. (2006). On the positive and negative effects of emotion work in organizations. European Journal of Work and Organizational Psychology, 15(1), 1-28. https://doi. org/10.1080/13594320500412199. 
Zapf, D., Vogt, C., Seifert, C., Mertini, H., \& Isic, A. (1999). Emotion work as a source of stress: The concept and development of an instrument. European Journal of Work and Organizational Psychology, 8(3), 371-400. https://doi.org/10.1080/1359432993 98230 .
Publisher's Note Springer Nature remains neutral with regard to jurisdictional claims in published maps and institutional affiliations. 